\title{
Occurrence of Ralstonia solanacearum race 2 biovar 1 associated with Moko disease of banana (Musa paradisiaca cv. Nipah) in Malaysia
}

\begin{abstract}
During June 2011 to March 2012, Moko disease symptoms were observed in banana cv. Nipah in two Malaysian states. The primer pairs ISRso19F/ISRso19R were used for defined identification of Ralstonia solanacearum race 2 strain. PCR amplification of all isolates produced a 1900 amplicon and exhibited 93\% phylogenetic similarity with reference strain (AF450275). Based on symptoms, biochemical tests, pathogenicity assay, molecular and phylogenetic studies, we concluded that the isolated bacterium was R. solanacearum race 2 biovar 1.
\end{abstract}

Keyword: ISRso19; Malaysia; Moko disease; Musa paradisiaca cv. Nipah; Ralstonia solanacearum race 2 biovar 1 